\title{
Description of a daily fishing activity from a small-scale fisherman in Central Greece (Korinthiakos Gulf)
}

\author{
Dimitrios K. Moutopoulos • Alexis Ramfos • \\ Catherine Moukas · George Katselis
}

Received: 26 February 2014/Accepted: 10 June 2014/Published online: 25 June 2014

(C) The Author(s) 2014. This article is published with open access at Springerlink.com

\begin{abstract}
High-frequency onboard monitoring of a fully dependent small-scale fisher operating in Korinthiakos Gulf during 2008-2009 (for 262 out of 418 fishing days) was taken place. The average annual daily landings and economic revenue were $4.9 \mathrm{~kg}(\mathrm{SD}=2.6)$ and $55.7 €(\mathrm{SD}=33.8)$, respectively. Multivariate analyses applied on either species landings composition or economic revenue revealed three main groups that were characterized by improvement of fisheries' landings and economic efficiency depending on group. Grouping might indicate fishing tactics adopted by the fisherman based on his prior experience to take advantage of the ecological behavior of the target species and market demands.
\end{abstract}

Keywords Daily landings $\cdot$ Species composition $\cdot$ Small-scale fisheries $\cdot$ Fishing tactics $\cdot$ Eastern mediterranean

\section{Background}

In Greek waters, the diversification of small-scale fishery in terms of spatio-temporal operations, types of fishing gear, target species, and market pathways (Tzanatos et al. 2005) hinders various difficulties in monitoring the small-scale fisheries of an area. In an effort to reduce this uncertainty, Tzanatos et al. (2006a) categorized Greek small-scale fisherman into three groups with reference to their dependence on fisheries; fully dependent, partially dependent and non-dependent. According to that classification, fully dependent fisherman: (a) exhibited the highest number of fishing days (229.4 days), (b) owned a small-scale vessel $(<7 \mathrm{~m})$, (c) mainly use gill and trammel nets, and (d) has very good knowledge/experience of the area and market demands. Such typology facilitates the focus on a certain small part of the fleet and offers the potential to bypass the aforementioned monitoring difficulties of small-scale fisheries.

In the present study, a fully dependent small-scale fisherman operating in Korinthiakos Gulf was monitored based on: (a) his systematic fishing activity because he has no other alternative sources of income, but fishing, (b) the fact that he is owned a small-scale vessel (5.8 m length), and (c) the main gear used. The definition of the basic characteristics of the small-scale fisheries in space and time is usually achieved through statistically planned samplings (Pelletier and Ferraris 2000) that provide a snapshot of the fishing activity throughout the

Electronic supplementary material The online version of this article (doi:10.1007/s40071-014-0067-5) contains supplementary material, which is available to authorized users.

D. K. Moutopoulos $(\bowtie) \cdot$ A. Ramfos $\cdot$ C. Moukas $\cdot$ G. Katselis

Department of Fisheries and Aquaculture Technology, Technological Educational Institute of Western Greece,

30200 Mesolonghi, Greece

e-mail: dmoutopo@teimes.gr 
year. In the present study, the high-frequency monitoring aims to reduce the uncertainty raised by the temporal heterogeneity of the Greek small-scale fishing activity (Tzanatos et al. 2005) to highlight decisions made by the fisherman in medium time scale. The selection of the fisherman was based on the above-mentioned criteria, whereas the choice of the study area (Korinthiakos Gulf) was based on its high contribution to the small-scale fishery; over 65.6 and $7.4 \%$ of the total landings in the area and in the Greek Ionian Sea, respectively (Moutopoulos and Stergiou 2012). Korinthiakos Gulf is also characterized by extended heterogeneity of the coastline and sea bed, a fact that increases the differentiation of the fishing tactics followed by the professional small-scale fishermen.

The aims of the study were to: (a) describe the species composition from a professional small-scale fishery, (b) define fishing tactics, target and incidentally caught species and (c) test the adequacy of the minimum landing sizes (MLS) based on the EU regulation 1967/2006 in relation to fishing tactics and target species.

\section{Methods}

Sampling

Fishing activity of a professional small-scale vessel (length $5.8 \mathrm{~m}$; engine horsepower $45 \mathrm{HP}$ ) operating in the southwest part of Korinthiakos Gulf $\left(38^{\circ} 16^{\prime} 50^{\prime \prime} \mathrm{N}, 22^{\circ} 11^{\prime} 40^{\prime \prime} \mathrm{E}\right)$ was monitored onboard by an independent observer during June 2008-August 2009 covering 262 out of 418 active fishing days (the whole number of fishing expeditions made by the fisherman). The fisherman operated at depths ranging from 50 to $300 \mathrm{~m}$ using gill (mesh sizes of 22, 24 and $32 \mathrm{~mm}$ nominal bar length; $500 \mathrm{~m}$ of length in June, $600 \mathrm{~m}$ during JulySeptember and $300 \mathrm{~m}$ during the remaining period) and trammel (mesh size of $22 \mathrm{~mm}$ nominal bar length; $700 \mathrm{~m}$ of length in June, $800 \mathrm{~m}$ during July-September and 1,000 m during the remaining period) nets. Fisherman also used longlines during a limited period of the year, especially when targeting Xiphias gladius during a very short period in early September.

Landings (without discards) data per species were recorded for 230 fishing days randomly distributed in each month, whereas total (i.e., all species combined) landings were recorded for the rest 32 fishing days. Sampling days were chosen at random between the fishermen fishing days, except during July-August 2008 and August 2009, when all fisherman fishing days' were monitored. Given that small-scale fishing activity peaks during summer (Tzanatos et al. 2005), the latter was recorded during two consecutive years (2008 and 2009). Total weight (wet weight in $\mathrm{g}$ ), total length (in $\mathrm{cm}$ ) and market value (euro $€$ per $\mathrm{kg}$ ) were recorded for each individual. Species market values were taken in situ, through an interview, by the fisherman and were referred to direct sale values. Numbers, weights and market values were expressed per 1,000 m of nets per day.

\section{Statistical analyses}

Species composition in terms of weight and market value was estimated for each fishing day separately. Secondly, to categorize individual fishing sets, cluster analyses were applied on two matrices (rows $\times$ columns): (a) species landings composition $\mathrm{x}$ fishing days and (b) revenue of species landings $\times$ fishing days. Data matrices were transformed using the double square root transformation, converted into triangular matrices of similarities using the Bray-Curtis coefficient and were subjected to group-average linking method. To test for differences between the identified groups, the non-parametric ANOSIM test was used. The contribution of each species to the average Bray-Curtis similarity within the aforementioned groups was also identified using SIMPER analysis (Clarke and Warwick 2001).

Total length for the most frequent and economically important fish species (those that cumulatively contributed $80 \%$ to the total landings and economic value) were compared in relation to their MLS. MLS of each species was taken from the most recent EU legislation (EU Regulation 1967/2006), whereas for some species not included in the above-mentioned regulation, the Greek Royal Decree (FEK 25A/26-1-1954) was taken into account. For the sake of consistency, Greek MLS values were converted from fork length to total length (Moutopoulos and Stergiou 2002) and complemented when necessary from length-length relations included in 
FishBase (Froese and Pauly 2013). Comparisons of mean landings, economic and TL values were performed using one-way analysis of variance (ANOVA) and post hoc Student-Newman-Keuls test (SNK) (Zar 1999).

\section{Results}

Overall, $1,255.2 \mathrm{~kg}$ was caught (230 fishing trials: 11,290 individuals) belonging to 70 species/genera (henceforth called species) (see Additional file 1). Constant annual market values were recorded for most species, apart from Merluccius merluccius, for which three market values were recorded (i.e., 12, 15, and $20 €$ )

Table 1 Mean daily landings $(\mathrm{kg})$ per 1,000 $\mathrm{m}$ of nets per month

\begin{tabular}{|c|c|c|c|c|c|c|c|c|}
\hline Year & Month & No of sampling days & Mean $W(\mathrm{~kg})$ & $\mathrm{SD}(\mathrm{kg})$ & Min $(k g)$ & $\operatorname{Max}(\mathrm{kg})$ & Mean Va $(€)$ & $\mathrm{SD}(€)$ \\
\hline \multicolumn{9}{|l|}{ Netters } \\
\hline \multirow[t]{7}{*}{2008} & June & 11 & $4.6^{\mathrm{c}}$ & 2.5 & 1.9 & 10.1 & $58.4^{\mathrm{b}}$ & 35.3 \\
\hline & July & 31 & $5.4^{\mathrm{c}, \mathrm{b}, \mathrm{a}}$ & 2.4 & 0.8 & 10.1 & $69.7^{\mathrm{b}}$ & 32.9 \\
\hline & August & 27 & $7.1^{\mathrm{a}}$ & 3.0 & 0.6 & 12.0 & $98.2^{\mathrm{a}}$ & 38.1 \\
\hline & September & 7 & $3.0^{\mathrm{c}}$ & 1.4 & 1.2 & 5.3 & $37.7^{\mathrm{c}}$ & 19.4 \\
\hline & October & 9 & $4.5^{\mathrm{c}, \mathrm{b}}$ & 2.3 & 2.3 & 7.5 & $51.5^{\mathrm{c}, \mathrm{b}}$ & 30.9 \\
\hline & November & 14 & $3.6^{\mathrm{c}}$ & 1.5 & 1.8 & 7.2 & $43.1^{\mathrm{c}}$ & 20.1 \\
\hline & December & 14 & $3.1^{\mathrm{c}}$ & 1.6 & 0.7 & 7.2 & $33.7^{\mathrm{c}}$ & 20.3 \\
\hline \multirow[t]{8}{*}{2009} & January & 12 & $3.5^{\mathrm{c}, \mathrm{b}}$ & 1.8 & 0.9 & 6.9 & $40.9^{\mathrm{c}, \mathrm{b}}$ & 24.6 \\
\hline & February & 12 & $7.1^{\mathrm{a}}$ & 3.7 & 3.1 & 15.9 & $76.7^{\mathrm{a}, \mathrm{b}}$ & 35.3 \\
\hline & March & 11 & $6.1^{\mathrm{b}, \mathrm{a}}$ & 2.8 & 1.8 & 11.1 & $70.5^{\mathrm{b}}$ & 30.1 \\
\hline & April & 16 & $4.5^{\mathrm{c}, \mathrm{b}}$ & 1.9 & 1.7 & 7.5 & $55.5^{\mathrm{b}, \mathrm{c}}$ & 22.2 \\
\hline & May & 11 & $4.7^{\mathrm{c}, \mathrm{b}}$ & 2.6 & 1.5 & 9.3 & $52.4^{\mathrm{b}, \mathrm{c}}$ & 27.6 \\
\hline & June & 11 & $4.0^{\mathrm{c}, \mathrm{b}}$ & 2.1 & 0.2 & 7.7 & $42.4^{\mathrm{c}}$ & 20.1 \\
\hline & July & 15 & $3.0^{\mathrm{c}}$ & 1.2 & 1.4 & 5.2 & $34.8^{\mathrm{c}}$ & 14.9 \\
\hline & August & 23 & $5.1^{\mathrm{c}, \mathrm{b}, \mathrm{a}}$ & 2.1 & 1.3 & 9.6 & $64.5^{\mathrm{b}}$ & 27.5 \\
\hline \multicolumn{9}{|c|}{ Longlines } \\
\hline \multirow[t]{2}{*}{2008} & August & 1 & 13.0 & & & & 260.0 & \\
\hline & September & 6 & 25.2 & 8.7 & 15.0 & 35.0 & 503.3 & 174.9 \\
\hline
\end{tabular}

Bold values indicate the highest values

$S D$ standard deviation, min and max minimum and maximum

a,b,c Groups of SNK Multiple Range Test with $a>b>c$

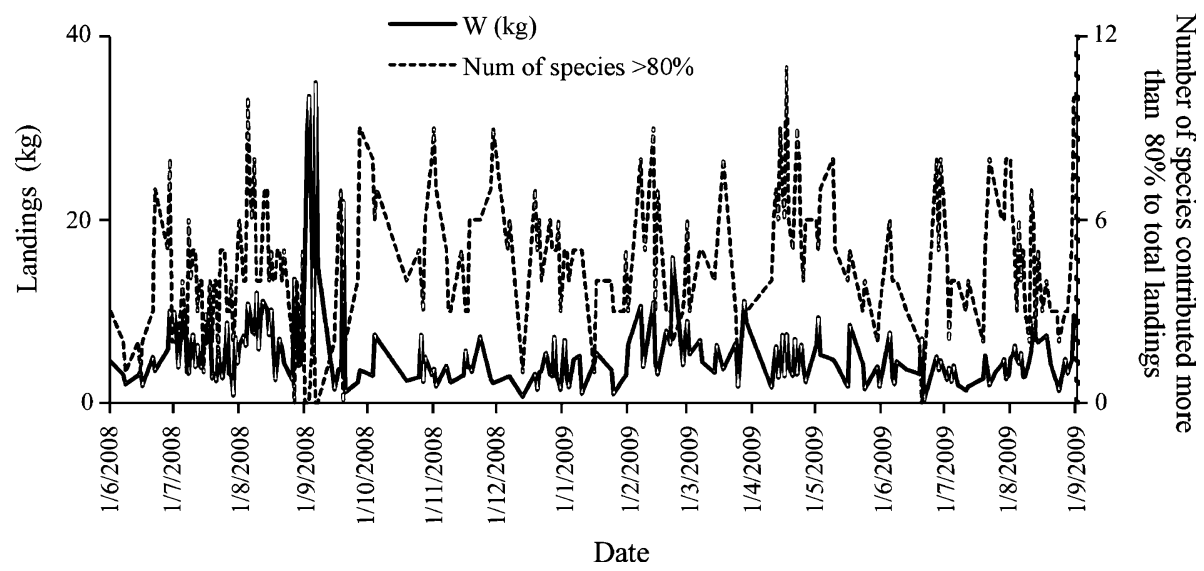

Fig. 1 Daily landings (kg/1,000 m of nets) and number of species contributing $80 \%$ of the total daily landings 
Table 2 Landings $(C \%)$ and market value $(V \%)$ composition per species to the average Bray-Curtis similarity (Av \%) within the groups identified by the multivariate analysis for

\begin{tabular}{|c|c|c|c|c|c|}
\hline \multicolumn{3}{|l|}{ Landings composition data } & \multicolumn{3}{|l|}{ Market value data } \\
\hline \multicolumn{6}{|c|}{ Group A (47 days): 30-31 July 2008/August 2008 and 2009} \\
\hline Av: $55.4 \%$ & $C \%$ & $S \%$ & Av: $51.6 \%$ & $V \%$ & $S \%$ \\
\hline Merluccius merluccius & 12.8 & 17.8 & Merluccius merluccius & 16.8 & 21.3 \\
\hline Natantia & 18.9 & 17.4 & Natantia & 14.0 & 17.7 \\
\hline Nephrops norvegicus & 15.5 & 15.1 & Nephrops norvegicus & 28.6 & 14.2 \\
\hline Phycis spp & 9.7 & 12.1 & Solea spp & 9.8 & 11.7 \\
\hline Solea spp & 8.1 & 11.8 & Phycis spp & 7.2 & 8.7 \\
\hline Micromesistius poutasso & 4.3 & 7.0 & Micromesistius poutasso & 1.6 & 4.2 \\
\hline Lophius spp. & 5.0 & 3.2 & Diplodus sargus & 2.7 & 3.4 \\
\hline Illex sp. & 4.8 & 2.9 & Lophius spp. & 5.5 & 3.0 \\
\hline Trachurus mediterraneus & 3.1 & 2.7 & Trigla spp. & 1.3 & 2.8 \\
\hline Trigla spp. & 1.6 & 2.3 & Illex sp. & 1.4 & 2.4 \\
\hline Cum \% & 83.8 & 92.3 & Cum \% & 87.4 & 89.4 \\
\hline Mean $( \pm$ SD) & 6.3 & & Mean (€/day) & 85.5 & \\
\hline \multicolumn{6}{|c|}{ Group B (11 days): 4/7, 21/7, 22/7, 29/7 in 2008 and 3/7, 5/7, 7/7, 11/7, 12/7, 19/7, 30/8 of 2009 } \\
\hline Av: $49.0 \%$ & $C \%$ & $S \%$ & Av: $49.7 \%$ & $V \%$ & $S \%$ \\
\hline Diplodus sargus & 29.5 & 28.0 & Diplodus sargus & 34.3 & 26.9 \\
\hline Merluccius merluccius & 12.0 & 18.0 & Merluccius merluccius & 14.8 & 18.3 \\
\hline Diplodus vulgaris & 9.4 & 15.3 & Diplodus vulgaris & 11.0 & 11.0 \\
\hline Trachurus mediterraneus & 8.0 & 11.4 & Pagrus pagrus & 8.5 & 7.8 \\
\hline Trigla spp. & 6.7 & 11.3 & Dentex dentex & 6.3 & 7.2 \\
\hline Pagrus pagrus & 5.5 & 6.6 & Trigla spp. & 5.7 & 7.2 \\
\hline Uranoscopus scaber & 4.3 & 2.3 & Trachurus mediterraneus & 3.1 & 3.5 \\
\hline Dentex dentex & 3.2 & 1.9 & Pagellus erythrinus & 3.0 & 3.2 \\
\hline Pagellus erythrinus & 2.7 & 0.8 & Mullus surmuletus & 2.5 & 2.6 \\
\hline Sphyraena sphyraena & 2.1 & 0.6 & Uranoscopus scaber & 1.3 & 2.0 \\
\hline Cum \% & 83.5 & 96.2 & Cum \% & 90.6 & 89.7 \\
\hline Mean (kg/day) & 3.2( & & Mean (€/day) & 41.7 & \\
\hline \multicolumn{6}{|c|}{ Group C (164 days): The remaining days during June 2008 to July 2009} \\
\hline Av: $45.0 \%$ & $C \%$ & $S \%$ & Av: $47.1 \%$ & $V \%$ & $S \%$ \\
\hline Merluccius merluccius & 18.6 & 16.4 & Merluccius merluccius & 25.5 & 18.2 \\
\hline Trachurus mediterraneus & 9.4 & 11.0 & Mullus surmuletus & 8.8 & 11.3 \\
\hline Lophius spp. & 9.3 & 8.6 & Pagellus erythrinus & 5.6 & 9.7 \\
\hline Diplodus sargus & 5.9 & 8.5 & Lophius spp. & 11.8 & 9.5 \\
\hline Mullus surmuletus & 5.2 & 8.0 & Trachurus mediterraneus & 4.0 & 8.2 \\
\hline Boops boops & 4.7 & 7.4 & Dentex macrophthalmus & 1.8 & 7.3 \\
\hline Pagellus erythrinus & 4.6 & 5.2 & Solea spp & 4.4 & 4.8 \\
\hline llex sp. & 4.2 & 5.0 & Boops boops & 2.0 & 4.5 \\
\hline Solea spp. & 3.1 & 3.9 & Citharus linguatula & 1.7 & 3.9 \\
\hline Dentex macrophthalmus & 2.9 & 3.2 & Uranoscopus scaber & 0.8 & 3.5 \\
\hline Sepia officinalis & 2.7 & 2.8 & Trigla spp. & 1.2 & 2.8 \\
\hline Uranoscopus scaber & 2.2 & 2.5 & Mullus barbatus & 2.7 & 2.5 \\
\hline Octopus vulgaris & 2.1 & 2.4 & Sepia officinalis & 1.6 & 2.3 \\
\hline Cum \% & 75.0 & 84.7 & Cum \% & 71.9 & 88.5 \\
\hline Mean (kg/day) & 4.6( & & Mean (€/day) & 54.3 & \\
\hline
\end{tabular}

$S \%$, is the percentage contribution to the Bray-Curtis similarity within groups, Cum $\%$, is the cumulative contribution, mean and $\mathrm{SD}$ is the average and standard deviation of the daily landings (in $\mathrm{kg} / \mathrm{day}$ ) and economic revenue (in $€ /$ day) the matrices consisted by the daily landings composition and market value per species caught 
Table 3 Minimum Landing Size (MLS), number of individuals $(N)$, mean total length (in $\mathrm{cm}$ ) and its standard error (SE) and percentage of the numbers of individuals with total length

\begin{tabular}{|c|c|c|c|c|c|c|c|c|c|c|c|c|c|c|}
\hline \multirow[t]{2}{*}{ Species } & \multirow[t]{2}{*}{ MLS } & \multicolumn{4}{|c|}{ Group A } & \multicolumn{4}{|c|}{ Group B } & \multicolumn{4}{|c|}{ Group C } & \multirow[t]{2}{*}{$P$} \\
\hline & & $N$ & Mean & SE & $\% \mathrm{MLS}$ & $N$ & Mean & SE & $\%$ MLS & $N$ & Mean & SE & $\% \mathrm{MLS}$ & \\
\hline Merluccius merluccius & 20 & 171 & $34.9^{\mathrm{a}}$ & 0.49 & 0.0 & 28 & $30.4^{\mathrm{b}}$ & 0.54 & 0.0 & 1209 & $29.0^{\mathrm{c}}$ & 0.17 & 21.1 & $*$ \\
\hline Solea vulgaris & 20 & 162 & $27.1^{\mathrm{a}}$ & 0.68 & 32.7 & & & & & 244 & $24.1^{\mathrm{b}}$ & 0.53 & 41.4 & $*$ \\
\hline Lophius spp. & 30 & 26 & $37.5^{\mathrm{a}}$ & 2.00 & 23.1 & & & & & 263 & $30.8^{\mathrm{b}}$ & 0.64 & 62.7 & * \\
\hline $\begin{array}{l}\text { Dentex } \\
\quad \text { macrophthalmus }\end{array}$ & $8^{\mathrm{A}}$ & 57 & 17.3 & 0.32 & 0.0 & & & & & 574 & 17.4 & 0.07 & 0.0 & \\
\hline Trigla spp. & $8^{\mathrm{A}}$ & 38 & $26.5^{\mathrm{a}}$ & 1.14 & 0.0 & & & & & 155 & $22.3^{\mathrm{b}}$ & 0.39 & 0.0 & $*$ \\
\hline Diplodus sargus & 23 & 118 & $17.5^{\mathrm{a}}$ & 0.14 & 100.0 & 181 & $17.7^{\mathrm{a}}$ & 0.11 & 98.9 & 756 & $17.2^{\mathrm{b}}$ & 0.07 & 99.3 & $*$ \\
\hline $\begin{array}{l}\text { Trachurus } \\
\quad \text { mediterraneus }\end{array}$ & 15 & 74 & 27.2 & 0.63 & 0.0 & 26 & 26.5 & 0.87 & 0.0 & 570 & 28.6 & 0.27 & 0.0 & \\
\hline Pagellus erythrinus & 15 & 24 & 17.4 & 0.37 & 14.3 & 21 & 17.9 & 0.73 & 14.3 & 728 & 18.7 & 0.12 & 7.6 & \\
\hline Uranoscopus scaber & $8^{\mathrm{A}}$ & 35 & 19.5 & 0.52 & 0.0 & 20 & 19.5 & 0.67 & 0.0 & 239 & 19.0 & 0.21 & 0.0 & \\
\hline Pagrus pagrus & 18 & & & & & 24 & 20.8 & 0.26 & 0.0 & 103 & 20.5 & 0.54 & 31.1 & \\
\hline Phycis spp. & $8^{\mathrm{A}}$ & 198 & 29.4 & 0.36 & 0.0 & & & & & & & & & \\
\hline $\begin{array}{l}\text { Micromessistius } \\
\text { poutassou }\end{array}$ & $8^{\mathrm{A}}$ & 147 & 26.1 & 0.16 & 0.0 & & & & & & & & & \\
\hline Diplodus vulgaris & 18 & & & & & 63 & 17.8 & 0.22 & 52.4 & & & & & \\
\hline Mullus surmuletus & 11 & & & & & & & & & 120 & 18.9 & 0.21 & 0.0 & \\
\hline Boops boops & $10^{\mathrm{A}}$ & & & & & & & & & 669 & 21.1 & 0.09 & 0.0 & \\
\hline Mullus barbatus & 11 & & & & & & & & & 365 & 19.0 & 0.11 & 0.0 & \\
\hline Citharus linguatula & $8^{\mathrm{A}}$ & & & & & & & & & 374 & 17.1 & 0.16 & 0.0 & \\
\hline
\end{tabular}

* Indicates significant differences of mean TL among groups (ANOVA: $P<0.05$ ) with a $>\mathrm{b}>\mathrm{c}$

A MLS values from the Greek Royal Decree (FEK 25A/26-1-1954) measured in fork length (see "Materials and Methods"). For the species listed $n>20$ for each group

corresponding to different sizes (Additional file 1). The maximum mean daily landings and daily economic revenue were recorded when the fisherman used longlines targeting X. gladius (6 days with $>22 \mathrm{~kg} / \mathrm{day}$ and $300 € /$ day, respectively), whereas for the rest fishing days, the mean daily landings and economic revenue were $4.9 \mathrm{~kg}(\mathrm{SD}=2.6 \mathrm{~kg})$ and $55.7 €(\mathrm{SD}=33.8 €)$, respectively (Table 1). One species (observed in nine days) to 11 species (observed in 17/4/2009) cumulatively contributed more than $80 \%$ of the daily landings and in almost half of the fishing days (110 out of total 230), more than five species contributed almost $80 \%$ of the total daily landings (Fig. 1).

Prior to cluster analyses, the six fishing days when $X$. gladius was caught and the 30 species contributing $<0.3 \%$ of the total weight and revenue removed from the dataset. The classification of the matrices applied both on the daily landings species composition and revenue per fishing day indicated that, at the 30.0 and $31.5 \%$ dissimilarity level, respectively, the 224 fishing days significantly (ANOSIM test: Global $R>0.530$; $P<0.05$ ) grouped into three main groups (Table 2). The species contributing to the similarity within the identified groups are shown in Table 2. Group A, which conducted during the end of July to the end of August (both for 2008 and 2009), was the most effective group in terms of mean fisheries landings and economic revenue (for both components: $\mathrm{A}>\mathrm{C}>\mathrm{B}$; Table 2 ) showing the highest variability per each fishing day for the above-mentioned components. Group B (11 days) took place during the same period as Group A, whereas Group C (166 trials) included fishing days of all seasons (Table 2).

Mean sizes of the target species caught (i.e., M. merluccius, Solea spp., Lophius spp. and Phycis spp., Trigla spp.) were significantly (ANOVA; $P<0.05$ ) higher for Group A than for the sizes of the same species for Group C (Table 3). Group B mostly consisted by Diplodus sargus and to a lesser extent by M. merluccius and Diplodus vulgaris. Group C was dominated by the small-sized individuals of M. merluccius, Lophius spp. and D. sargus and to a lesser extent by Trachurus mediterraneus, Mullus surmuletus and Mullus barbatus. 
For seven out of 17 species, the percentages of individuals per group with lengths smaller than MLS ranged from $7.6 \%$ (for Pagellus erythrinus in group C) to $100 \%$ (for D. sargus in Group A) (Table 3). The proportion of the number of individuals with mean sizes caught smaller than the MLS was higher in Group C, for the species M. merluccius, Solea spp., Lophius spp. and Pagrus pagrus than in the other two groups (Table 3). In contrast, for the species P. erythrinus and D. vulgaris the most illegal individuals were caught in Groups A and C, respectively (Table 3). D. sargus recorded the highest number of illegal individuals caught for the entire fishing period ( $98.9 \%$ of the total individuals caught).

\section{Discussion}

Small-scale fisheries have a great socio-economic importance in peripheral and ultra-peripheral regions (Guyader et al. 2013) as well as in data-poor areas (Tzanatos et al. 2012), such as the Eastern Mediterranean waters. In the present study, sampling covered more than $50 \%$ of the total fishing activity during a 15-month fishing period (418 fishing days) of a small-scale fisherman. The fisherman of the present study can be considered as fully dependent fisherman, because he conducted more fishing days in an annual period compared with the mean number of fishing days estimated for a fully dependent fisherman in Greek waters (i.e., 331 fishing days during June 2008-May 2009 versus 209.2 days per year: Tzanatos et al. 2005). The average annual daily landings per $1,000 \mathrm{~m}$ of nets were $4.6 \mathrm{~kg}(\mathrm{SD}=2.8)$ and peaked during summer $(5.3 \mathrm{~kg})$. Although the data were based on one fisherman and for a limited area, thus it is rather uncertain to outline conclusions about the entire fishing fleet in the area; however, it highlights the way that a fisherman makes decisions in medium time scale.

The study fisherman can be also considered as a fully dependent small-scale fisherman, because his "low income-low risk" strategy is consistent with the fishing strategy characterized as the fully dependent smallscale fisherman in Greek waters (Tzanatos et al. 2006b). This strategy showed the existence of few "blank days" (only $2.5 \%$ of fishing operations with total landings $<1 \mathrm{~kg}$ ) and the presence of species with high commercial value in most fishing trials (Table 2). Fisherman preferred to keep constant clients and fish values throughout the year, than following the 'demand/value' rule of the market. This explains the constant market values of fish irrespectively of the season.

Apart from the above-mentioned catholic strategy and seeking the maximization of profit a fisherman, based on prior experience, can switch between alternative tactics during short-term periods (Salas et al. 2004) to take advantage of the: (a) feeding, (b) reproductive behavior and (c) the availability of the target species in accordance with market demands. Groups A and B, which were the most effective groups in production and income, are implying an opportunistic tactic during short-term period (Tzanatos et al. 2006b). In fact, the fisherman adopts a "higher income-higher risk" by targeting species of highly commercial value (large sizes of M. merluccius, N. norvegicus, Diplodus spp.) during a period with high demand for fish due to tourism (July-August). Such tactics proved to be quite efficient in terms of daily income but in parallel seemed to increase the risk as indicated by the higher variability of both fisheries landings and economic revenue during this period (Table 2). Non-targeted species also contributed in the landings (incidentally caught species) of these groups, some of them caught occasionally (i.e., Trachurus mediterraneus, P. pagrus), ensuring additional income to the fisherman from species other than the targeted ones.

The group with the highest number of fishing days (75\% of fishing days) was Group C conducted at muddy shallow depths (30-100 m) all year round targeting mostly $M$. merluccius and to a lesser extent, a wide variety of species that ensured low but persistent production and income (Table 2). This tactic has been also observed in the adjacent Patraikos Gulf (Métier Tr1; Table 1 in Tzanatos et al. 2006b) conducted during DecemberApril at shallow waters $(25-75 \mathrm{~m})$ by vessels smaller than $12 \mathrm{~m}$.

Figure 2 showed the landings per monitored fishing days of the most frequent species caught in relation to their spawning period according to Tsikliras et al. (2010) for fish species, Relini et al. (1998) for N. norvegicus and Abelló et al. (2002) for Natantia. In particular, the maximum fishing landings for M. merluccius, N. norvegicus, Lophius spp., M. surmuletus, P. erythrinus, Trachurus mediterraneus coincided with their spawning season. The fisherman is experienced on the feeding and reproductive behavior of the target species, even though he was not always aware of their reproduction cycle. For instance, M. merluccius was the most important species in terms of abundance and economic revenue throughout the year a fact that is in accordance 

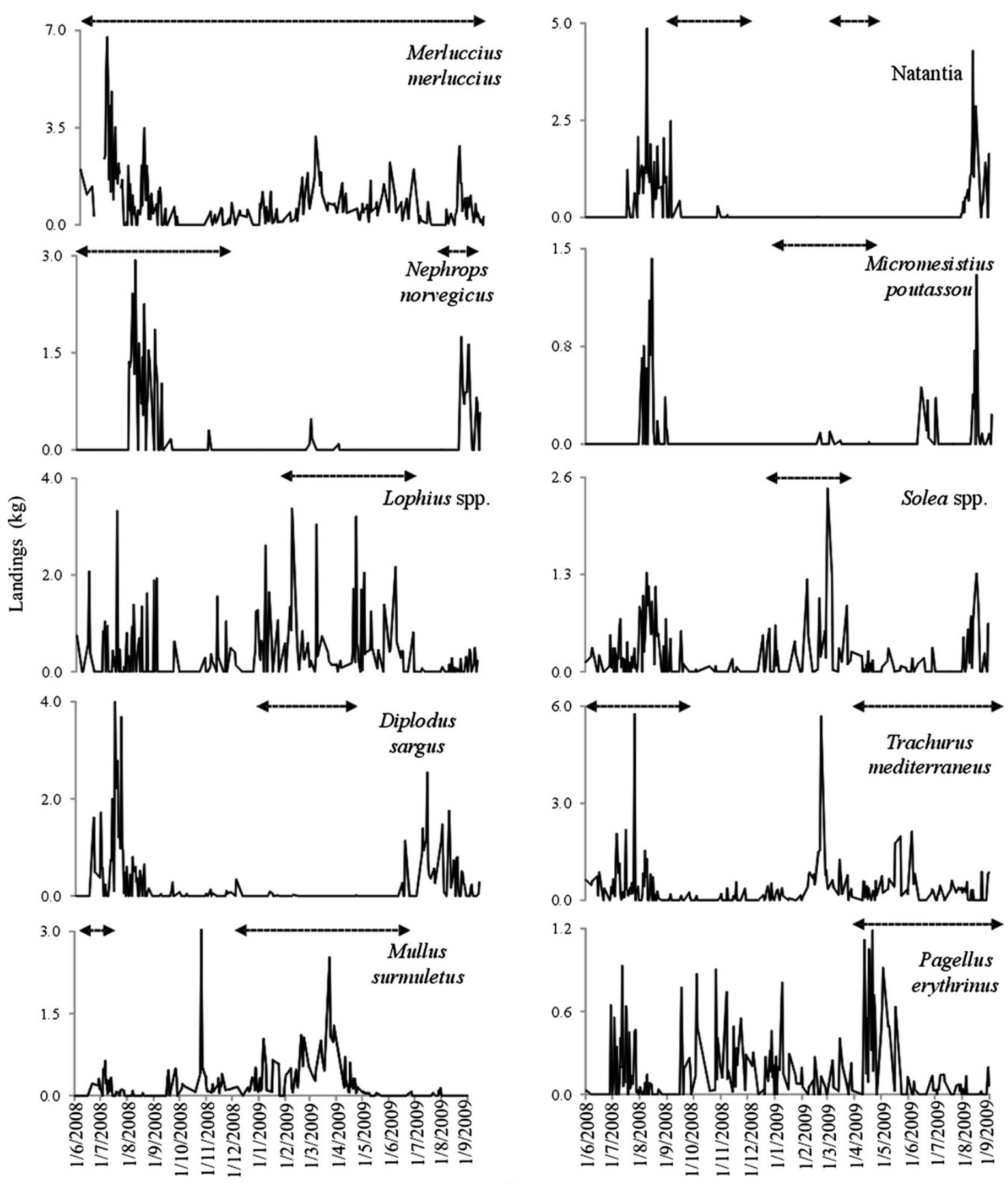

Date

Fig. 2 Daily landings (kg/1,000 m of nets) per species. Horizontal arrows indicate the spawning period of each fish species

with other studies in the area (Korinthiakos and Patraikos gulf; Tzanatos et al. 2006b). N. norvegicus, which also makes up a great part of the landings in deep waters during summer, increases its mobility by changing habitat from the bottom where it usually lives (Aguzzi et al. 2004).

The present study also highlights the ecological sustainability of the small-scale fishing gear (Stergiou et al. 2009). Apart from $D$. sargus, the mean percentage of illegal individuals per group of fishing tactics was relatively low $(<27 \%)$. In the case of $D$. sargus, almost all individuals were below the MLS for the species. This issue has also been reported for other Greek areas (Ionian Sea: Stergiou et al. 2009; Patraikos Gulf: 
Tzanatos et al. 2006b) and has been attributed to the higher MLS set recently for the species (from 12 to $23 \mathrm{~cm}$; ER 1967/2006). Many demersal stocks in the E Mediterranean are much smaller in sizes than their W Mediterranean and N Atlantic counterparts (Stergiou et al. 1997), whereas however, this is not reflected in the corresponding Mediterranean MLSs and further contributes to the ecological inadequacy of the MLS measure.

\section{Conclusions}

The present study highlights the importance of the individual experience of a professional small-scale fisherman in integrating the biological behavior of fish species for maximizing his economic benefit. The high frequency monitoring aims to the identification of alternative fishing tactics during short-term periods the fisherman take advantage of the feeding, reproductive behavior and market demands.

Authors' contribution AR and GK have conceived the project, designed the experiment and have contributed in reviewing the manuscript. CM has conducted experiments and searched literature. DKM has contributed to the data analysis, writing, and reviewing the manuscript. All authors read and approved the final manuscript.

Acknowledgments The authors would like to thank Mr. and Mrs Moukas for their valuable help in the field work.

Conflict of interests The authors declare that they have no competing interests.

Open Access This article is distributed under the terms of the Creative Commons Attribution License which permits any use, distribution, and reproduction in any medium, provided the original author(s) and the source are credited.

\section{References}

Abelló P, Abella A, Adamidou A, Jukic-Peladic S, Maiorano P, Spedicato MT (2002) Geographical patterns in abundance and population structure of Nephrops norvegicus and Parapenaeus longirostris (Crustacea: Decapods) along the European Mediterranean coasts. Sci Mar 66(Suppl. 2):125-141

Aguzzi J, Sarda F, Allue R (2004) Seasonal dynamics in Nephrops norvegicus (Decapoda: Nephropidae) catches off the Catalan coasts (Western Mediterranean). Fish Res 69:293-300

Clarke KR, Warwick RM (2001) Change in marine communities: an approach to statistical analysis and interpretation, 2nd edn. PRIMER-E, Plymouth

Froese R, Pauly D (2013) FishBase. http://www.fishbase.org. Accessed July 202013

Guyader O, Berthou P, Koutsikopoulos C, Alban F, Demanèche S, Gaspar MB, Eschbaum R, Fahy E, Tully O, Reynal L, Curtil O, Frangoudes K, Maynou F (2013) Small scale fisheries in Europe: a comparative analysis based on a selection of case studies. Fish Res 140:1-13

Moutopoulos DK, Stergiou KI (2002) Length-weight and length-length relationships of fish species from the Aegean Sea (Greece). J Appl Ichth 18:200-203

Moutopoulos DK, Stergiou KI (2012) Spatial disentangling of Greek fisheries landings by fishery during 1928-2007. J Biol Res Thess 18:265-279

Pelletier D, Ferraris J (2000) A multivariate approach for defining fishing tactics from commercial catch and effort data. Can J Fish Aquat Sci 57:51-65

Relini LO, Zambino A, Fiorentino F, Massi D (1998) Reproductive patterns in Norway lobster Nephrops norvegicus (L.), (Crustacea Decapoda Nephropidae) of different Mediterranean areas. Sci Mar 62(Suppl. 1):25-41

Salas S, Sumaila UR, Pitcher T (2004) Short-term decisions of small-scale fishers selecting alternative target species: a choice model. Can J Fish Aquat Sci 61:374-383

Stergiou KI, Christou ED, Georgopoulos D, Zenetos A, Souvermezoglou C (1997) The Hellenic Seas: physics, chemistry, biology and fisheries. Oceanogr Mar Biol 35:415-538

Stergiou KI, Moutopoulos DK, Armenis G (2009) Perish legally and ecologically: the ineffectiveness of the minimum landing sizes in the Mediterranean Sea. Fish Manag Ecol 16:368-375

Tsikliras A, Antonopoulou E, Stergiou KI (2010) Spawning period of Mediterranean marine fishes. Rev Fish Biol Fish 20:499-538

Tzanatos E, Dimitriou E, Katselis G, Georgiadis M, Koutsikopoulos C (2005) Composition, temporal dynamics and regional characteristics of small-scale fisheries in Greece. Fish Res 73:147-158

Tzanatos E, Dimitriou E, Papaharisis L, Roussi A, Somarakis S, Koutsikopoulos C (2006a) Principal socio-economic characteristics of the Greek small-scale coastal fishermen. Ocean Coast Manag 49(7-8):511-527 
Tzanatos E, Somarakis S, Tserpes G, Koutsikopoulos C (2006b) Identifying and classifying small-scale fisheries metiers in the Mediterranean: a case study in the Patraikos Gulf, Greece. Fish Res 81:158-168

Tzanatos E, Castro J, Forcada A, Matic-Skoko S, Gaspar M, Koutsikopoulos C (2012) A Métier-Sustainability-Index (MSI25) to evaluate fisheries components: assessment of cases from data-poor fisheries from southern Europe. ICES J Mar Sci 70(1):78-98

Zar JH (1999) Biostatistical analysis, 4th edn. Prentice Hall Inc., New Jersey 